\title{
ПРИЛОГ ПОЗНАВАЊУ ЛЕКСИКЕ ОБИЧАЈА КРШТЕНА КОД СРБА У ДУНАВСКОЈ КЛИСУРИ
}

У овом раду скренута је пажња на значај проучавања лексике у вези са обичајима повезаним са рођењем и крштењем детета код Срба у селима Белобрешка, Дивич и Стара Молдава у Дунавској клисури у Румунији. Осим што су према хронолошком принципу описани поменути обичаји, сачињен је и речник културолошке лексике. Како у проучаваним обичајима жени припада значајно место, посебна пажња посвећена је лексеми бабица. Сачињавање речника културних термина у вези са обичајима око рођења и крштења детета на простору српских села у Дунавској клисури у Румунији треба да послужи као подстрек за даља проучавања српске обичајне лексике на овим просторима ради употпуњавања шире етнолингвистичке слике.

Кључне речи: Дунавска клисура, обичаји, рођење, крштење, етнолингвистика, културеме.

1. Увод. Насељена места Белобрешка, Дивич и Стара Молдава, која географски припадају Дунавској клисури у Румунији, претежно су насељена српским становништвом. ${ }^{3}$ У селима Дунавске клисуре у периоду од 31 . маја до 3. јуна 2017. године спроведено је теренско истраживање у оквиру пројекта Истраживање културе и историје Срба у Румунији, који се реализује уз помоћ Центра за научна истраживања и културу Срба у Румунији, при Савезу Срба у Румунији. Том приликом забележено је близу три стотине минута материјала, при чему је нарочита пажња била усмерена на прикупљање података о обичајима и веровањима који су у вези са породичним циклусом, тј. рођењем детета, као и обредом крштења којим дете улази у хришћанску духовну заједницу и који се дешава непосредно после рођења. ${ }^{4}$

\footnotetext{
${ }^{1}$ irena.cvetkovic.teofilovic@filfak.ni.ac.rs

${ }^{2}$ Рад је урађен у оквиру пројекта Истираживаюе кулитуре и истиорије Срба у Румунији, који се реализује уз помоћ Центра за научна истраживања и културу Срба у Румунији при Савезу Срба у Румунији, као и пројекта Срйски језик некад и сад: лингівистичка исирраживать (360/1-16-10-01), који се реализује на Филозофском факултету у Нишу.

${ }^{3}$ О говорима Срба у Дунавској клисури уп. радове: Томић, 1987; Милорадовић, 2007; Драгин, 2018; Лончар Раичевић-Цветковић Теофиловић, 2018.

${ }^{4}$ Истраживачи на терену били су поред аутора овога рада и доц. др Александра Лончар
} 
1.1. Када су у питању обичаји и лексика традиционалне културе Срба у Дунавској клисури, посебну пажњу привлачили су обичаји кумачења (Милорадовић, 2013: 131-137; Сикимић, 2018), те лексика свадбених обичаја (Милорадовић, 2013: 128-131), затим начини светковања крсне славе (Аксић, 2018; Трубарац Матић, 2018), као и Божића (Ивановић Баришић, 2018). Овоме се може придружити и студија из фолклористике о присутним демонолошким предањима код Срба у Дунавској клисури на примеру демонских бића тодоровции/тодоронции/тудоронции (Ђорђевић Белић, 2018). Поједини обичаји Срба у селима Дунавске клисуре описани су и у енциклопедијском речнику Словенска митологија, рађеном под редактуром Светлане Толстој и Љубинка Раденковића (CM, 2001: 520).

1.2. Ритуал крштења је религијски ритуал који, строго узевши, не припада ритуалима животног циклуса. У хришћанском свету он је, међутим, спојен са „прехришћанским постнаталним ритуалима, па је тако саставни део комплекса ритуала везаних за рађање” (Радуловић, 2002: 77). Прехришћански постанатални ритуали спадају у тзв. ритуале прелаза, док се обред крштења као литургички усредсређен ритуал, може сматрати иницијатским, односно обредом инкорпорације (Жикић, 2002: 116). Жикић истиче, међутим, да се ритуал крштења може посматрати и као део једног ширег обреда прелаза, што је прихваћено и у овом раду (2002: 116).

Отуда нису строго одвајани обичаји у вези са рођењем од оних у вези са крштењем, будући да су први нека врста припреме за сам чин крштења, тј. посматрани су овде као једна целина, односно као обреди прелаза. На овакав приступ указивала су и сама казивања информатора из горепоменутих села који ни сами нису разграничавали ова два сегмента већ су их третирали као саставне делове шире целине. Такође, није вршена дихотомија на обичаје и веровања у вези са новорођенчетом и на обичаје и веровања у вези са породиљом.

1.3. Рад је урађен са циљем и да се укаже на један архаични туре у коме жена има запажено место и улогу, ${ }^{6}$ присутан у поменутим се-

Раичевић и доц. др Татјана Трајковић са Филозофског факултета у Нишу.

${ }^{5}$ Н. И. Толстој за архаичне области истиче да то нису само области добре очуваности. Архаичну област карактерише и постојање чврстог система духовне културе националног типа, услова функционисања те културе и низа црта, елемената и атрибута, својствених другим, релативно изолованим областима истога типа у границама савремене Славије (Толстој, 1995: 17).

${ }^{6}$ С. Петровић истиче да се тзв. матријархатски културни модел, у коме жене и девојке заузимају централно место у обичајима, јавља на простору источног дела Балканског полуострва. Овај тип културе карактерише приношење жртве хтоничним божанствима, веровање у бића демонског света, везаност за природу и лунарну митологију, доминантност породичне заједнице и сл. (Петровић, 2002: 25-28). У матријархатском културном моделу 
лима Дунавске клисуре као део културне баштине Срба, ${ }^{7}$ са жељом да се указивањем на поједине термине у вези са обичајима око рођења и крштења допринесе сачињавању лингвокултуролошког речника Срба у Румунији.

На основу снимљеног материјала на терену ${ }^{8}$ реконструисани су обичаји у вези са рођењем и крштењем, према хронолошком следу догађаја, који карактеришу села Белобрешка, Дивич и Стара Молдава, са мањим варијацијама, на које је приликом сачињавања јединственог записа скренута пажња. ${ }^{9}$

\section{2. Обичаји у вези са рођењем и крштењем код Срба у Дунавској клисури.}

Кад се роди дете, трећега дана баба са флашом воде и босиљком, увијеним у бело платно иде код Господина попе да тражи зламење (Белобрешка), име на зламење (Дивич), име на зламен или зламену (Стара Молдава). Тим именом које попа каже дете зову све док се не крсти, а понекад то име остане детету дуго година поред крштеног имена које даје кум. Воду донету од куће Господин освешта, па се она долива по мало када се дете купа, све док се не утроши. ${ }^{10}$

Трећега дана од рођења детета око поноћи долазе судије, милостиве (Белобрешка), милостиғе (Дивич), милостивне (Стара Молдава). За њихов дочек праве се мале погачицее, стави се вода, свећицее и платно (Белобрешка), односно на столицу се стави један пешкир, тањир са водом и огледало (Дивич), или се мете брашно, со и вино, како би се по траговима видело јесу ли милостивне долазиле (Стара Молдава). Некима милостиве поруче

жена се јавља у улози првосвештенице, она приноси жртву, бави се врачањем, она пророкује и тумачи догађаје из природе и живота у симболичко-магијском кључу (Петровић, 2002: 33).

${ }^{7}$ На овом месту издвајамо само неке напомене информатора којима се указује на то да поједини обичаји и лексеме припадају управо људима српске националности. Информатори са којима је обављен разговор у селима Дунавске клисуре, са поносом истичу: код нас Срба; йо су обичаји наши; обичај наш итд.

${ }^{8}$ Овом приликом захваљујемо информаторима: А. Г. (рођ. 1935) и Ђ. Н. (рођ). 1932) из Белобрешке, Ж. М. (рођ) 1944) и В. С. (рођ.1929) из Дивича, као и А. Ж. (рођ). 1938) и М. А. (рођ). 1927) из Старе Молдаве на топлом дочеку и жељи да сваком госту изађу у сусрет.

${ }^{9}$ Сами информатори често су истицали да су њихови обичаји добри и лепи. У појединим домаћинствима они се и дан данас спроводе, мада се прикупљени материјал односи, пре свега, на период око половине 20. века. Поједини информатори наводили су да су обичаји различити од села до села: Свака кујна кува друкще. Такође, критиковали су нову моду по којој се крштење обавља суботом, последњег дана у седмици, како истичу, а не недељом, како би требало да буде.

${ }^{10}$ А. Г. из Белобрешке једина наводи да се вода узима после крштења, доноси кући, и та „свештана” вода се долива по мало при купању детета. 
да ће дете умрети, али је, свакако, најважније шта ће одлучити трећа која пресуђује.

Новорођенчету се ставља ирвен конац око десне руке да га не урекну. Код бебе под јастук се ставља сечиво, тј. нека мала бритва и поскурник (Белобрешка), односно поскурник, босиљак, нож и бели лук (Дивич). Мајка, такође, носи сечиво са собом јер на сечиво ништа не наилази.

Шест недеља мајка не сме да изађе из куће увече кад зађе сунце, нити је дозвољено да бебина одећа заноћи у дворишту; понегде се веш сушио до крштења у кући, све док се дете не крсти. Чак се и вода из корита у којој се дете купало просипа само на сред дворишта, где пролазе кола и марва.

Чим се дете роди прави се мала повојнища. Тада долазе најближи да виде бебу. У Белобрешки и Дивичу обично се прави погача, нешто се испржи или се испече пиле и стави се једна главица црног лука да мајка има млека, заједно са другим поклонима за бебу. Сви ти поклони стављају се на сто, а тата дочекује госте тако што корпу подигне да дете порасте велико. Погачу начиње мушко дете ако је у кући рођено женско, и обрнуто, како би се догодине у кући родило дете другог пола. Велика повојница обично се правила на сам дан крштења.

Док дете не наврши месец дана, обичај је да се крсти. Најпре се иде код кума и пита за име, када кум каже име, крштење се закаже и иде се у цркву. У цркву се носи обавезно крзница (бело платно) у којој је новац. Крзница је увезана плавом, односно црвеном, розе или белом машном, у зависности од пола детета. Том крзницом попа брише дете када га замочи у воду. Крзнииу и свећу за крштење купује кум.

На крштење иду обично кум и кума, дететов отац и баба, тј. бабицุа, жена која носи дете. Мати остаје код куће. Док се дете крсти она код куће ако има женско дете, треба да ради неки женски посао: по мало да штрика, да шлингује, да шије, да преде, да броји паре, да чита, да пише, да чисти мало, а ако има мушко дете, онда треба да ради мушку радюу: и тада треба да чита, да уђе мало у шталу, да секиром мало удари на пањ, да мало гура кола, да узме неки ланац, вилу и сл.

Сам чин крштења најдетаљније је описан у Белобрешки, можда због чињенице да је информатор из Белобрешке - Ђ. Н. певала у црквеном хору. Она истиче да Господин и кум крсте дете. Кум чита Вјерују и понавља шта му Господин попа каже. Они три пута иду око стола, потом Господин узима мушко дете и иде у олтар да га благослови, а ако је у питању женско дете, клекне пред олтаром и ту се моли за дете. Дете се не купа већ се замочи у освештану воду. Косу коју му одсече, изгори попа мало на свећи. ${ }^{11}$

После крштења кум долази код домаћина на фруштук, будући да не једе све док се дете не крсти. Кум се, по традицији, дарује кошуљом. Уколико се тог дана прави велика повојница, касније кум са породицом долази

\footnotetext{
${ }^{11}$ А. Г. из Белобрешке, међутим, истиче да се прамен косе који попа исече детету на крштењу чува неколико година у кући, а то потврђује и М. А. из Старе Молдаве.
} 
поново, сви се веселе, а потом се гости испраћају и дарују кум и чланови његове породице.

3. О лексемама баба, бабица, зламење и крзница. Несумњиво место у обичајима у вези са рођењем и крштењем детета заузима жена, као што је већ истакуто. Она је задужена да умеси погачу за малу повојницу, за припремање дарова за милостиве, за тумачење њихових порука, за заштиту мајке и бебе од урока и сл. Жена у овим обредима прелаза има и једну нарочиту улогу. Женска особа - баба, тј. бабица, носи дете заједно са кумом на крштење. Осим што носи дете, улога бабице на самом крштењу је да дете ослободи одеће и поново га обуче. Један од информатора саопштава да током обреда крштења поп помиње и име бабице, поред кумовог.

3.1. Сами информатори о овој улози наводе да је баба, тј. бабиц̧а жена која носи дете у цркву: „она која носи”. То може бити и биолошка баба новорођенчета, али и тетка, ујна, дакле, млађа особа. В. С., родом из Соколовца, наводи: „Носила сам дете, у цркву сам била ко баба”, док А. Ж. (Стара Молдава), која, иначе, нема своје деце, истиче: „Ја сам била бабица на три места, три тако сам носила у цркву”. Ђ. Н. из Белобрешке уз термин бабица, наводи и да се на румунском каже „моша”. ${ }^{12}$

3.2. Разматрајући обичаје при рођењу детета у селима Дунавске клисуре и Пољадије, Борислав Крстић истиче много заједничких особина (Крстић, 2015: 197-201), које се у главним цртама подударују и са овде изнетим описом. Разлику између лексеме бабица у значењу „примаља” и лексеме бабица у значењу: „жена која с дететом у наручју одлази у цркву на крштење”, Крстић потенцира на графијском плану, тако што у овом другом случају лексему бабица исписује курзивом (2015: 200).

3.3. Речник радимског говора региструје, међутим, следећа значење лексеме бабиц̧а 1. (дем.) бабица. 2. примаља, акушерка. 3. наковањ за откивање косе. 4. хлепчић који се меси о даћама (Томић, 1989: 9), али не и значење које произлази из овде наведеног описа обичаја крштења у селима Дунавске клисуре.

3.4. Бројне лексеме у вези са обичајем крштења бележи Речник српских говора Војводине, пружајући нам могућност да бар овлашно, без подробнијих испитивања, упоредимо два система духовне културе Срба: с једне и

\footnotetext{
${ }_{12}$ Овом приликом није разматран узајамни однос двеју култура на подручју Дунавске клисуре - српске и румунске.
} 
са друге стране румунске границе. ${ }^{13}$ Под одредницом бабица даје се, између осталог, и значење: „жена која указује помоћ приликом порођаја, акушерка”, али се међу примерима налази и следећи: „носи дете бабица на крштење”, при чему су наведени бројни пунктови (РСГВ, 2000: 64-65), док се под одредницом баба (РСГВ, 2000: 64) наводи значење из Крашове: „примаља („баба”, једна од најстаријих жена у селу и суседству) донесе новорођенче до црквених врата и на улици спусти га на земљу". Није тешко уочити да се у наведеном речнику значење лексеме бабица као акушерке не раздваја јасно од значења коју ова лексема има у обичајим везаним за крштење. Могуће је да је улогу бабице на крштењу могла имати и права бабица, тј. акушерка у оно време, ${ }^{14}$ али забележени обичаји у селима Дунавске клисуре јасно налажу да бабица на крштењу детета може бити било која жена или девојка која је одабрана за ту улогу, најчешће из редова најближе дететове родбине, као што су баба, тетка, ујна и сл.

3.5. За разлику од лексема зламење (зламен, име на зламен, зламена) и крзница $a,{ }^{15}$ чију широку распрострањеност у истом значењу, забележеном и у говорима Дунавске клисуре, потврђује и Речник САНУ (РСАНУ, 1971:125; РСАНУ, 1978: 521 ), лексема бабица у наведеним областима има статус културеме, ${ }^{16}$ о чему до сада није било речи.

3.6. Имајући у виду пример речника културолошке календарске лексике, дат у раду Љ. Недељков о културолошком истраживању лексике Срба у Румунији (Недељков, 2013: 168-170), могућа дефиниција лексеме бабица у оквиру семантичког поља породични обичаји (рођење и крштење) је следећа: „жена, најчешће баба по оцу, тетка или ујна, која новорођенче заједно са кумом носи у цркву и брине о детету у цркви тако што му скида и облачи одећу за потребе крштења; обилази са кумом око стола за време крштења”.

\footnotetext{
${ }^{13}$ Треба напоменути да Речник срӣских говора Војводине не даје податке само за Војводину већ и за банатске пунктове у Румунији.

14 У доба када су се порођаји почели обављати у болници, вероватно је улога жене која иде за зламење и носи дете у цркву са праве бабице прешла на рођаку блиску породици новорођенчета, која је добила исто име - бабица, будући да је тај задатак својевремено заиста обављала права бабица, примаља, акушерка. Због чињенице да је бабица на крштењу често бивала биолошка баба детета, познат је назив и баба за жену која носи дете у цркву.

15 Лексема крзница у испитиваним пунктовима у области Дунавске клисуре има нешто уже значење него у РСАНУ (уп. РСАНУ, 1978: 521) и РСГВ (уп. РСГВ, 2004: 178).

${ }^{16}$ Културолошка лексика (културеме) јесте „лексика за појмовни свет везан за свакодневни живот чије је основно концептулано значење јединствено на целом простору српског језика (односно на оној територији где су такве лексеме познате), а њихово културолошко значење долази до изражаја кроз додатни семантички садржај којим се тај културни модел разликује од оних на другим просторима (Недељков, 2013: 161).
} 
У наставку рада даје се речник општеупотребних лексема које имају додатни семантички садржај у обичајној лексици која је везана за рођење и крштење детета у селима Дунавске клисуре у Румунији.

\section{4. Речник културолошке лексике у вези са обичајима око рођења и крштења}

Астал, -а м „Сто на који се ставља храна која се донесе за малу повојницу, заједно са поклонима, намењеним беби и породиљи.”

Баба в. бабица

Бабица, -е ж „жена, најчешће баба по оцу, тетка или ујна, која новорођенче заједно са кумом носи у цркву и брине о детету у цркви тако што му скида и облачи одећу за потребе крштења; обилази са кумом око стола за време крштења."

Бели лукац „Allium sativum, зачинска биљка која се заједно са другим реквизитима ставља под главу новоређенчета против урока."

Босиљак, -а м „Osimum basilicum, гранчица ове биљке која се заједно са флашом воде носи у цркву када се иде за зламење; гранчица која се заједно са другим реквизитима ставља под главу новорођенчета против урока."

Брашно, -а с „Млевена пшеница која се користи за справљање хлеба; брашно се остављало треће ноћи, заједно са сољу и вином да би се по траговима видело да ли су долазиле милостиве да прорекну судбину новорођенчету."

Бритва, -е ж „Сечиво које се ставља под главу новорођенчета да га штити против урока."

Вино, -а с „Вино се обично доносило уз погачу за малу повојницу. Користило се и као дар за милостиве.”

Даривати, дарујем „Поклањање разних ствари беби по завршетку крштења када и породица дарује кума и његове чланове породице.” Замочити, замочим „Потапање детета у воду за време крштења уместо ранијег купања."

Зламење, -а с „То је прво име које детету надене поп пре крштења и које носи до крштења."

Кобасица, -е ж „Прерађевина од свињског меса која се пржи за малу повојницу."

Прамен косе „Прамен дечије косе који се одсече на крштењу и чува у некој марамици неколико година после крштења.”

Кошуља, -е ж „Дар који се дарује куму после обављеног крштења; дар који се даје попу за крштење.”

Крзница, -е ж „Бело платно које кум купује за крштење, а поп о то 
платно брише дете за време крштења или покваси то платно, па њиме додирује дете."

Купати, купам „Потапањем у освештану воду чишћење детета за време крштења; сада се дете само замочи у воду или покваси."

Леј, -а м „Румунски новац који кум ставља у крзницу као дар на крштењу детета."

Машна, -е ж „Плава или црвена тканина којом се увезује крзница, у којој је и новац, намењена крштењу новорођенчета."

Милостиве, милостивне, милостиње ж пл. „Три женске особе које треће ноћи око поноћи проричу судбину детета."

Мрс, -а м „Време када није пост и када може да се прави мала повојница."

Мушка радња „То је посао који мајка која не иде на крштење ради код куће да би мушко дете тако исто радило кад порасте: гура кола, узима у руке неки ланац, вилу и сл."

Недеља, -е ж „Дан у седмици када се правило крштење.”

Пиле, -та с „Врста печења, обично се пиле носило уз погачу и вино на малу повојницу."

Пљунути, пљунем „Избацити одређену количину пљувачке од стране особе која је урекла дете, како би се пљувачка намазала детету на чело да се скине урок."

Погача, -а ж „Врста хлеба који се месио за малу повојницу. Њу угризом начиње женско дете ако је у кући рођено мушко, тј. мушко дете ако је у кући рођено женско, како би се догодине рађала деца супротног пола."

Погачице ж пл. „Врста производа од теста који се правио треће ноћи од рођења детета када се чекају милостиве да прорекну судбину детета."

Поскурник, -а м „Предмет у облику крста који се ставља заједно са бритвом, белим луком и босиљком под главу новорођенчета против урока."

Пресећи, пресечем „Погледати дете или марву урокљивим очима.”

Радити, радим „Обављати одређене послове за време крштења док се дете крсти, будући да мајка остаје код куће. Она ради послове намењене женском или мушком детету: пише, чита, пева, броји паре, штрика, шлингује, шије, пере неки суд, чисти, чука, гура кола, иде у шталу и сл."

Свећа, -а ж „То је свећа коју кум купује за крштење, осим крзнице.” $\mathbf{C o},-$ и ж „Брашно, со и вино остављани су преко ноћи како би се видело да ли су милостиве походиле дете.”

Стакло, -а с „Посуда која се напуни водом када се пође за зламење и из које се вода сипа по мало у корито кад год се купа беба." 
Столица, -е ж „Предмет за седење на који се за милостиве треће ноћи по рођењу детета остављало бело платно или пешкир, затим вода, вино, погачице, огледало и сл."

Субота, -е ж „Последњи дан у седмици када није прихватљиво правити крштење."

Фруштук, -а м „Доручак који се припрема за кума. Будући да кум не једе ништа пре него што се дете крсти, код куће домаћини после крштења припремају фруштук."

Црвен конац „То је конац који се детету веже на десну руку са циљем да га штити од урока."

Црни лук „Allium сера, поврће и зачин. За малу повојницу уз јело се обавезно стави и главица црног лука да би мајка имала млека."

5. Закључак. На значај састављања речника културолошке лексике у вези са рађањем детета и крштењем указује и успостављено поређење са Речником културолошке календарске лексике Љ. Недељков (Недељков, 2013: 168-170), где уз лексему астал нпр. стоји лексикографска дефиниција: „сто, на Бадњи дан испод столњака ставља се слама и џак, а на столњак сва храна и пиће за Бадње вече", док се уз лексему босиљак наводи следеће: „Osimum basilicum, гранчица ове биљке којој се приписује заштитна моћ забоде се у средину божићног колача" (Недељков, 2013: 168), тј. истим лексемама придодаје се другачије културолошко значење у зависности од испитиваних обичаја. ${ }^{17}$

На крају овог кратког прилога о културним терминима у вези са обичајима око рођења и крштења детета на простору српских села у Дунавској клисури у Румунији, доносе се транскрипти забележених текстова који су послужили као основа овог истраживања. Ове текстове одликује „повезаност радњи и обраћања предметима, који имају симболички смисао, као и говорна повезаност, која је с њима у вези" (Толстој, 1995: 57). Ако се обред схвати као такав текст, говорећи семиотичким језиком културе, могу се издвојити три кода или три стране језика: вербална (усмена - речи), реална (предметна - предмети, ствари) и акционална (делатна - дејства/радње) (Толстој, 1995: 57). Обреди прелаза, о којима је у овом раду било речи, укључују све три компоненте, а проучавање међусобног односа компоненти један је од важних задатака, будући да је то предуслов стилистичке анализе текста. У будуће циљеве, свакако, спада и одређивање изодокси, тј. граница одређених појава, што би омогућило боље познавање духовне културе Срба који данас живе на просторима Румуније, културе која је истовремено обележје идентитета, али и резултат специфичног опстанка у мултиетничким срединама на периферији.

\footnotetext{
${ }_{17}$ Уп. овде наведена значења под одредницама асйал и босиљак.
} 


\section{Текстови}

\section{Белобрешка}

Разговор вођен 31. маја 2017. године.

Разговор водиле Ирена Цветковић Теофиловић (И. Ц.) и Александра Лончар Раичевић (А. Л.). Присутан мештанин Предраг Марковић (П. М.).

\section{А. Г., 1935.}

Кад се крсти дете? (И. Ц.)

Кад се роди дете код нас у току месец дана то је обичај да треба дете да се крсти. Иде се код кума, се пита за име, кум нам каже име и ми закажемо кад оћемо да га крстимо и онда га водимо у цркву.

Ко иде све у цркву? (И. Ц.)

Кум и кума и ко носи: баба, мислим, бабица, оћу да кажем, која носи дете. То је или баба (или ја) или моја ћерка. Ја сам одступила мојој ћерки. Тако је било. И смо крстили онда Славомира. Тамо после кад се крстио дођемо кући, се праве нешто ручка, ондак дођу у посету фамилија, прво то се зове код нас мала повојница, се дође код детета. То се прави нека погача, се стави сир у тањир, шта имамо, кобасице, сланине пржимо и једна главица црна лука да има мама млека.

Шта се носи све у цркву кад иде дете да се крсти? (И. Ц.)

Носи се једна крзница, платно бело, машна и неки леј у то платно увијено.

Шта је крзница? (И. Ц.)

То платно - то је крзница, се каже код нас, и се стави неки леј у то платно, и мало пића, мало нешто, шта има куј, то носи.

Онда се вршу те дужности. Се крсти се и се дође кући. Мало на ручак, и тако. Посе ко оће дође, фамилија, мислим није обавезно сви. После кад правимо по други пут повојницу онда дођу сви кога зовемо и кумови опет и сви. Ми дарујемо кумове и кумови бебу. И тако.

Шта му дарују? (И. Ц.) да буде.

Па неку стварчицу, неко оделанце, а обавезно по неки леј, то треба тако, каже,

Шта ради поп у цркви? (И. Ц.)

Па га крсти, њене обичаје.

Да ли скидају бебу голу? Да ли купају или прскају? (А. Л.)

Стављају у воду. Више прскају, а пре су купали децу више. Кад је зима су имали мало млаку воду да не ставу децу баш у ладну тако воду. Тако је било, се дете замочи у воду. Дођемо сви кући и тако, толико.

Шта је друга повојница? (А. Л.)

Онда је да зовеш фамилију, кога оћеш твоју браћу, сестре, тетке, то све ближња фамилија и кум обавезно да дође. Онда ми дарујемо кума и кум бебу, како куј мого пре.

Да ли је обичај да неко из куће не иде на крштење? (И. Ц.)

Код нас из куће то није било, није било ни у село то, само покајити понеки.

А мати? (П. М.) 
Мати не иде у цркву, мати остане кући.

Ко онда носи дете у цркву? (И. Ц.)

Бабица носи дете у цркву. (Није обавезно да је баба, може бити млада девојка. Она га свлачи и после крштења облачи. Податак мештанина П. М.).

Зашто мајка не иде на крштење? (И. Ц.)

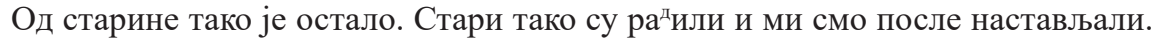
И сад мајка не иде. А за то време док ми идемо у цркву да се крсти беба, ондак мајка, она ради неке послове да се беба научи нешто да ради: чука или пере суд неки, нешто тако, ради.

Да ли се дете крсти за неки црквени празник? (И. Ц.)

Обично недеља. Само се гледа да није пост. Ондак то се не крсти.

Шта се још дешава прве недеље после рођења детета? (П. М.)

Прве недеље после рођења, на трећи дан, онда каже да седимо да слушамо шта ће да суду судије (милостиве) беби. На трећи дан онда се опе ${ }^{\mathrm{T}}$ стави на једну столицу једна чаша вина, једна чаша воде, бело платно. Онда седимо до поноћи да слушамо шта ће да кажу детету, шта ће да се деси. Неким кажеду да ће да умре, да знате.

Како јаве то? (И. Ц.)

Не знам како... тако... Ја знам кад смо Славомира... ја и баба Роза, нико није тео да седи, само ми. Ми седимо и слушамо. Кад је било дванаест сати, он је имао три дана, трећи дан звонце тако цин, цин, ко кад иду деца за врбицу, тако. И он се насмејао. Моја мајка, она каже: „Јао, љуби га баба, има да буде сретан у његов живот". Нисмо чуле да су казале да ће да умре, или ће да буде болесан, или нешто шта ће да проведе. Само то толико. (Погодиле су. (И. Ц.)) Звонце звони и ја гурам бабу Розу и она мене гура. Мисли да сам заспала, па не чујем. „Сам будна, чујем ја.” „Да чујеш.” „Ја чујем”. Ми гледамо ома у Славомира, он се насмејао.

Било му је тачно. (И. Ц.)

Суђено. (А. Л.)

До сад му било добро, фала Богу.

Да ли се детету сече прамен косе и шта се дешава са тим? (И. Ц.)

Се увеже сас том водом што се носи у цркву. Кад се крсти, онда се напуни једно стакло воде, кад се купа се ставља у воду ди се купа дете, и тај прамен од те косе кад му се сече то се увије у неку марамицу и се држи до три-четири године тако то да стоји. Посе и на годину онда опет му одсечу косу, то кум.

И та коса са крштења се чува и после се заборави на то? (И. Ц.)

Се чува и се чува, после временом се...

Зашто се чува? (И. Ц.).

Углавном се чува много година, та коса.

Како смо пре купали, није било баја ко сад и то, корито сваки пут, воду сипамо из стакла, ту свештану воду, с крштења. (Носи се вода из куће и узме се после крштења? (И. Ц.)) Носи се пуно стакло, после тамо се пресврати, и се узме кад попа свешта, га крсти, онда се напуни од те воде друге. И сас тем се купа дете док се не потроши та вода, сваки дан или ујутру или увече кад се купа.

Да ли су ваши унуци крштени исто тако? (А. Л.)

Јесте, јесте, сви су крштени. У свако село је други обичај. Ћерка, она удата у друго село. Кад се крстила њо на ћерка, они правили по њинем обичају, није по нашем. Синово дете кад се крсти, то је код нас. 
Да ли дете има неко име пре крштења? ( П. М.)

Има дете прво име што идемо у цркву код Господина попе. Ми питамо и он каже како да се зове. После тога идемо код кума кад оћемо да га крстимо. И кум ни каже име његово. Обично кумово остане.

Како се зове ово име што каже попа? (П. М.)

Зламење, зламење се зове то име прво што каже попа.

А како дете у кући зову док се не крсти? (И. Ц.)

По том од попе.

Да ли знате које је име то било? (И. Ц.)

Знам, Душан. Душан Славомирова она прабаба волела, није волела Славомир, каже она не уме да каже то, он је био први у село име, и баба не зна да каже, она каже он ће да буде мој Душан, љуби га баба. И после га звала дуги година, после се мало научила. Њега сви волели кад се родио. Кума Душка га крстила. Они нису давали да иду учитељи у цркву. Кум је био учитељ. Кума Душка га крстила. А посе, Млађа, радио све шта треба. Тако је било време.

\section{Ђ. H., 1932.}

Обичаји наши су доста добри и лепи. Дете кад се роди, по обичају нашим, трећега дана одма идемо у свету цркву за зламење. Господин попа, он надене име. Зламење да док се беба не крсти у цркву. И под тим имену треба да се зове беба док се не крсти да добије од кума друго име. Код куће баба узме флашу воде и босиљак и увијено у један леп салвет, пешкир и то иде код Господина попе и тражи зламење. Кад купају бебу се долива по мало.

Онда се крстиду и праву се весеља. Носу се, иду кум и отац. Мати не иде код нас у цркву кад се крсти. Код нас Срба, ако је женско, треба да седи у кућу, да по мало штрика, да помало шлингује, да по мало преде, да броји паре, да чита, да чисти мало, ако је мушко, опет треба и да чита, мати онда треба мало да уђе у шталу, мало да почисти, са секиром мало да удари на пањ. И тако је било. То су обичаји наши. Дођеду из свете цркве и се настави весеље. Пре се правило у куће. А сад се правиду весеља у дому, у град, у...

По кафанама. (И. Ц.)

Да. По кафанама. Сад тако се праву весеља.

За крштење није била музика у кући? (И. Ц.)

И музика, да. И за крштење музика, како да не.

Шта се ради у цркви? (А. Л.)

Иду за кума прво. Иде момак, отац детета, и још ближњи куји су од фамилије. Иду за кума и дођу, дођеду код момка, ди је рођено дете и онда од отуд пођу и идеду сви у свету цркву.

Која жена носи дете? (И. Ц.)

Која жена? Ја сам носила моју унуку, а млађу унуку је носила моја ћерка; моје ћерке ћерку, моју унуку, Јованка је носила, ујна. Она је носила опет је било, што они кажу, бабица, моша, како кажу Румуни.

Ову најстарију, то ми била прва милос, ја сам тела ја да носим, нисам дала ни ћерки, ни другом. Него ја сам. Посе кад се родила ова млађа, ондак је моја ћерка носила њу, а кад се њена ћерка родила, моје ћерке, ондак је носила моја снаја Јованка, она је носила Анку. 
И тако весеље траје до зоре, што се каже.

А у цркви шта раде? (И. Ц.)

У цркву се крсти, мајка је певала у хор, хор пева кад се крсти дете, Господин и кум крстиду, Вјерују читаду и Оче наш. По обичају кум треба да чита Вјерују, кој зна, а куј не зна чита из књиге, из Јеванђелија чита. И шта му Господин попа каже то он понавља. Иду трипут око стола. Господин узме дете ако је мушко иде у олтар унутра га благослови, ако је женско клекне пред олтар и ту се моли за дете. Кум и кума прихвату дете и тако дођу до куће.

Сад замочу дете. Од богојављања водица што остане, што је свештана, они ставу у ове велике балоне и то стоји гор на таванчићу у цркву. Кад је зима они ту воду угреју на струју. Господин умочи цело дете. И настаје весеље.

Да ли секу детету косу? (И. Ц.)

Да сече. Косу сече и стави мало на свећу изгори то мало косе. Кум донесе крзницу, платно ако је мушко везано машном плавом, а ако је женско са црвеном или рози. И о ту крзницу Господин попа уви дете, брише кад га замочи у воду.

Да ли се чува косица? (И. Ц.)

$\mathrm{He,} \mathrm{не} \mathrm{чува} \mathrm{се,} \mathrm{то} \mathrm{изгори} \mathrm{та} \mathrm{косица} \mathrm{мало.}$

У цркву шта се све носи? (И. Ц.)

Носи се поклон Господину, кошуља. Пре се давало и пешкир, сад кошуља. Сваки купи кошуљу.

Пре какви пешкири се давали? (П. М.)

Ткани било, љуби те мајка, ткани, што ткале маме, и мајка имала. Дала сам и мојема унукама по један.

Код куће шта се прави за крштење? (И. Ц.)

Се спрема ручак, по реду супа, соса, меса, кромпира, печење, торте, колаче. Правиле су све жене у кућу. И супа се теглила са оклагијом, и секла сас ножом. Сад на машину. Иде брже. А пре се секло с ножом, па ситно, лепо.

А детету шта се дарује? (И. Ц.)

Сад већином паре дају. Пре је било кошуљице, бенкице, капице, пелене, како је било пре на метер фланел, бео. Нису биле пензије, нису биле плате. Сељаци немаду не знам колико добитак. Они од производње шта живу. А саде сваки има па плату, па пензију, и се снађу. Пре сељак је доста тешко живео.

Да ли излази дете негде из куће пре крштења? (И. Ц.)

Сад излази. Пре за шест недеља мајка не сме дизађе увече кад зађе сунце, више нема шта да тражи, нити да остану пеленке ил бенкице ил нешто у двориште. То све треба док сунце не зађе да се скупи. И вода из корита итнеш на сред авлије куд пролазу кола, куд пролази стока, марва. Не да итнеш било где. Сад то нема. Тај обичај сад је несто. Мама носи бритву, сечиво у џеп, не дај Боже, за сваки случај, да има код ње, тако је добро, тако стари казали. На сечиво не наилази ништа.

А код бебе шта се ставља? (И. Ц.)

И код бебе опет се стави једно сечиво, и како смо имали ми, и сад имамо, поскурник, кад се прави колач, па се убоде тај крсто на колач за резање, за славу, тај поскурник, то је као крс један, то се стави беби под главу, и једно сечиво, мала бритва то се стави код бебе под главу.

А црвен конац? (И. Ц.)

Црвен конац му бацу на руку, вежеду му на руку црвен конац ради урока. 
А како се гледа какав ће детету живот да буде? (И. Ц.)

Трећи дан се правиду тако мале погачице, и се стави вода, и свећице, и платно. Милостиве дођу у по ноћи и онда оне решавају судбину детета. Има неки виду, неки чују. Бог зна. Три женске, тако се зоведу милостиве, и оне решавају судбину, и једна, и друга, и трећа.

Да ли се гледа да је неки празник или само да је недеља кад се дете крсти? (И. Ц.)

Недеља. Већином деца се крсту недељом и онда се и слави.

Кад дође први пут родбина, шта донесу? Како се зове то? (П. М.)

Повојницу малу. Малу повојницу кад се дете роди, кад дође из болнице кући, онда се прави погача и се пече пиле и главица црнога лука, то се стави у котарче све, и поклон за бебу, кошуљице, панталоне, и вина, и се носи (неки пржи кобасице, неки пече пиле, неки донесе сира с погачом, како ко) и онда то се стави на сто.

Ко доноси? (И. Ц.)

Носу бабе, носу ујне, тетке, а тата дочека и он подигне корпу да порасте дете велико. Зоведу и децу. Ако је женско, мушко да начне погачу, да би родили догодине сина.

\section{Дивич}

Разговор вођен 1. јуна 2017. године.

Разговор водиле Ирена Цветковић Теофиловић (И. Ц.), Александра Лончар Раичевић (А. Л.) и Татјана Трајковић (Т. Т.)

\section{Ж. М., 1944.}

Да ли се сећате каква су крштења овде била пре? (И. Ц.)

Се сећам, баба Живка се сећа како је било крштење. Лепо је крштење кад се крстиду деца. Се веселимо кући сви, кумови. После правимо ко свадбу, пуно света, пуно астали тунака. Кад се крсти у цркву се даје поклоне, се, код нас, тако је обичај код нас.

Повојницу велику сам имала за ову унуку. Сам преко три стотине душа сам имала. У камин, како кажемо ми, у дом. И тамо сам частила кумове. То изнесемо котарицу са стварима, сад обичај новце, а пре било ствари. Ондак кумове дарујемо, па ондак дарујемо све њине, у кумство који су туна. Ондак овамо ове жене што кувале. Музика... кошуље на њи. Музика њи десетину: тунака армуникаши, тамбураши, пуно света свудер. Изнеседу колаче, у кола играду. Тако је било пре, а сад је више друкше.

Можете ли све од рођења детета па све до крштења да нам кажете? (И. Ц.)

Кад се роди дете до два месеца га држимо, ондак о ма се крсти, нема да се држи млого, ко што сад обичај га крстиш великога. Месец дана, два, о ма га крстиду и о ма весеље. Куј је у могућост, тај је правио.

Ко је име давао детету? (И. Ц.)

Кум.

А пре тога? (И. Ц.)

Пре није давао. Не мож да даิ ми нико.

А попа? (И. Ц.) 
Ни попа не да. Попа да за зламење. Идеш ти. А код кума идемо дамо ми.

Ко иде све на крштење? (И. Ц.)

Иде отац, сас оцом иде кум и кума. Иде баба носи то дете. Она га носи у цркву. Из цркве му да њему и дођеду кући. Кум иде око астала сас попом. Попа га посе га свуче па га намаже мало са ладном мало водом, не га купа. Мало му исече косе.

Шта се ради са косом? (И. Ц.)

Косу ти да Господин и чуваш. Ако изгубиш, изгубиш.

Не гори попа косу на свећи? (И. Ц.)

Не. Ја нисам видела.

Мајка не иде на крштење? (И. Ц.)

Мајка не, мајка је кући.

Шта ради кући? (И. Ц.)

Чека тунака сас тима гостима чека дете.

Да ли ради нешто по кући? (И. Ц.)

Па играш, певаш, да би то дете играло, да би певало тунака.

Да ли неки посао мајка обавља у кући? (И. Ц.)

Пише, чита, штрика, рачуна, узме свеску. То је било пре. Нема то више шта је било пре.

После ручак? (И. Ц.)

То је фруштук. Кад је попа на јутрење ондак се крсти дете. Само фруштук и кум иде кући.

Шта се спрема за фруштук? (И. Ц.)

Било меса, било је кромпире, пај; закољемо јаре, смо му дали супе. Ко кад је ручак.

Да ли се месио неки хлеб? (И. Ц.)

Купили смо леба нисмо месили.

А погача? (И. Ц.)

Погачу кад се роди дете идеш у шпитаљ. Ондак му носимо погачу, му носиш лука да има мати млека.

Шта је мала повојница? (И. Ц.)

Дођеш кући, видиш бебу и платиш да купи момка, јел купи девојку мушкарац, даш неку пару.

Шта је велика повојница? (И. Ц.)

Кад је крштење ондак је већа повојница.

Да ли се детету ставља нешто против урока? (И. Ц.) тету.

Се ставља црвен конац на руку детету да ге не урекнеду. То се стављало де-

А испод јастука? (И. Ц.)

Није се стављало ништа. Код нас то није. Ништа. То има на нека села. Свака кујна кува друкше.

А кум шта донесе детету? (И. Ц.)

Он донесе крштеницу детету и свећа везана сас било мушки плава машна, а било женско црвена машна.

Шта детету дарује кум? (И. Ц.)

Новце. 
Судбина детета како се одређује? (И. Ц.)

Милостиње оне дођу трећу ноћ и ти пресуду. Ко кад те неки ондак тера да се успаваш. Те оне успавају да не би чула, знаш. Прва овако, друга онако, а трећа пресуди. Откуд ће дванес сати, одједаред краде ме сан и обара ме, чула сам врата да се отворила, ко нека зима, стра и сам заспала и нисам знала да л' су биле. Да л' нису биле. Још горе би ми било. Боље кад не чујеш. Је страшно. Боље кад нисам то чула.

Да ли ви верујете у то? (А. Л.)

Па ја верујем.

Да ли се обистинило то што су рекле милостиве? (А. Л.)

Па има. Истина. Ето је сам превела сас мојем дететом. То је истина. Толико и толико му рекли ће да живи, тај дан кад се родио у тај дан је и умро.” Боље кад не знаш.

Да ли сте бајали некада деци против урока? (И. Ц.)

Ја само узмем воде и ондак наменим...

Мој син кад се родио, тако био леп, па сам га држала дебо, па уз пенџер, тако. И пређе један човек: „О, овај је леп”, Илија се зове, „ко луче”, каже. И га уреко је, кроз пенџер га уреко. Он одједаред почо да вришти, претура очи, плаве му се будзе. Моја свекрва: „Само да идеш за пљувачку код њега.” Она отидне за пљувачку. Он неће да пљуне у шољу. Његова жена: „Само да пљунеш”. Пљунуо је, моја свекрва донесе, га прекрсти и му га намаже на чело. Ома ревенирало дете и ома друкше. Овако би умро. Има много од урока оће да умиреду деца. Има ко има гадне очи, га пресече, не само дете, и марву.

\section{В. С., 1929, родом из Соколовца}

Да ли се сећате какви су обичаји када се дете крсти? (И. Ц.)

Тако се спреми, имаш кума, дете окупаш га, обучеш га, чисто, био јастук бео, јорганче било озгор штиковано, под њега било плаво. Ту се уви дете и с тем крштењаком, с тем се покри јастук и дође кум и га узме.

И га носи баба, која бабица та узме дете, а кум иде поред бабице. У цркву га раздрешу и узме га кум у руке, упалу свећу и носу га, га крстиду.

Да ли мајка иде у цркву? (Т. Т.)

Мајка није пре ишла, а сад иде. Мајка остане кући, ако је мушки, ондак ради мушку радњу у кући да би дете радило.

Шта ради? (И. Ц.)

Мало гура кола, мало неки ланац узме, вилу. А кад је девојка ондак мати и пише и чита и мало по кући ради да би дете радило. Сад није. Ако је девојка, ондак мати штрика, шлингује, нешто шије и чита, пише, да би дете знало све. Е, сад није, сад је друкше.

Кад кум дође кући оде се спреми фруштук јер кум не фруштукује док се не крсти дете. Посе је. Ми спремимо леп фруштук, и га дочекамо, и га послужимо да фруштукује; кум доби кошуљу, увежемо с кошуљом, и кад је, иде кући. Ако се прави повојница, тај дан када се крсти, ондак кум иде кући и оде се спрема за повојницу за госте и посе се купу гости. Ако га крстиш пре, ниси правио још повојницу, ондак кум иде кући и не дође. А кад је за повојницу онда кум дође пос е подне, кује си зво да ти дођеду на повојницу они дођу, ручаду, обдариш кога још кум кога доведе, одонуд: жену, децу. И поново дам куму кошуљу. Како да иде кум без кошуље посе? 
Како се зове та повојница? (И. Ц.)

Чим се дете роди, ондак се прави погача, се пржи нешто и то се раскрши погача и то је мала повојница. Ондак дођеду родбина, комшије, донесу погачу, у тањир пржено месо, неко јаје и флашу вина, баци се на астал све те бабе што дођу, жене донесу, ту се рашири, ондак газда греје ракије и поји те бабе што су дошле и једу погаче, и пржено, и кућевно, и њино што донели, и све то, и молу Бога. То је мала повојница, чим се роди. Посе правиш велику повојницу.

Шта ради поп у цркви када крсти дете? (И. Ц.)

Пои његову службу.

Да ли купа дете? (И. Ц.)

Не купа га. Мало кваси платно то што добијеш од кума. Крзница се каже. Ондак то умочи мало у воду и мало дете тако укваси. Сад се не купа дете.

Да ли му шишају косу? (Т. Т.)

Може и то да биде. Нисам баш видла. Носила сам дете, у цркву сам била ко баба. Ми држимо дете годину дана не шишамо га.

Када се крсти дете? (Т. Т.)

Кроз недељу дана се дете крсти. Да је дете кршћено. Сад годинама не крстиду дете.

Да ли сте гледали судбину детета? (И. Ц.)

Бациш на столицу један пешкир, у тањир воде, босиљка, огледало. То преноћи трећу ноћ. То смо бацили да се реши судбина трећу ноћ.

Како се зову те жене што решавају судбину детета? (И. Ц.)

Милостиве, оне суду судбину, и од Господа Бога највише.

Када се дете роди да ли идете код попа да му он да неко прво име? (Т. Т.)

Узмеш флашу воде, идеш у цркву и носиш ту флашу воде, тамо попа освешта ту воду и каже име како је, то је попино прво име, а после кум.

Како се зове то прво име? (И. Ц.)

Кад ми се родио унук, сам била ја у цркву и било пред Св. Илију и попа реко да биде Илија. Сад мој унук има имендан на Св. Илију.

А како се зове то име? (И. Ц.)

На зламење.

Шта се спрема за ручак? (И. Ц.)

Углавном у мрс се правила повојница. Шта имаш: живину, печемо гуске, закољемо неко јагње, велико тако, прасе.

Којим данима се крштење правило? (Т. Т.)

У недељу. Пре се пра'ило у недељу и свадбе и повојнице. Субота је последњи дан недеље. То није било у реду пре да се тако прави. Увек се пра'ило у недељу.

Шта се детету даровало за крштење? Шта му је кум доносио? (И. Ц.)

Кум детету донесе крзницу за крштење у цркву. Крзница је платно, чисто бело. У ту крзницу неки новац баци и с једном машном га веже, ако је мушко баци плаву машну, ако је девојка црвену, рози, белу. Мете у крзницу неки новац и вежеду и с тем се крсти дете. Умочи мало те крзнице у воду и мало покваси дете.

Да ли је кум даровао нешто од главе, капу, блузу, ципеле? (Т. Т.)

Целокупно. И блузна, и капа, и целокупно све.

А та вода која се освешта када се иде за зламење? (И. Ц.).

Кад се дете купа то метеш по мало ту воду у корито док се не потроши. 
Да ли је дете излазило напоље пре крштења? (И. Ц.)

Нисмо изнесивали. Зато се пре крстила деца за недељу дана. Ниси смео дизиђеш напоље ни мати није требала дизиђе напоље кроз стреју да иде по авлији негде по сенку док дете нема шест недеља. То се знало да није требала та мати да иде, да изгуби млеко.

А веш када је морао да се скупи? (И. Ц.)

Његов веш оперемо и ондак ширимо ту, у собу, не носимо напоље на жице, ту смо сушили код шпорета и када је топло, лето, док се не крсти дете. Кад се крсти, ондак можеш да шириш напоље ал опет да не омркне, да скупиш раније.

Да ли се детету стављало нешто против урока? (И. Ц.)

Да. Имала сам поскурник, што се баца на бабице се праиле пре, то ви не знате шта је, Исус Кристос ту пише, то држимо под главу, нож, босиљак, бели лукац, то смо држали код детета под главу. И кад је велики био.

А ако га ухвати урок? (Т. Т.)

Баба мора да угаси воде...

\section{Стара Молдава}

Разговор вођен 2. јуна 2017. године.

Разговор водиле Ирена Цветковић Теофиловић (И. Ц.) и Александра Лончар Раичевић (А. Л.).

\section{А. Ж., 1938.}

Да ли знате о обичају крштења да нам нешто кажете? Све да нам испричате од када се дете роди. (А. Л.)

Иде се ома за зламену код господина попе. Ти носиш воду од куће. Ја сам била бабица на три места, три тако сам носила у цркву, знате. Попа ти каже зламену, како он оће. Дођеш кући то донесеш. Носиш бебу у цркву тамо Господин те пита како оћеш да се зове, кума пита. Саде даду име родитељи како они оћеду. Попа га крсти.

Како изгледа чин крштења? (А. Л.)

Чин крштења се одреши све, одсечу од косе, водицу те све намаже, праву крстове на њега, се опкаља око астала. Бабица и кум посе носи око астала и онда кажу име и Господин каже како се зове, како се бабица зове која носи у цркву, и кумови, и то ти кажеду.

Када се крштење обавља? (А. Л.)

Пре кад се роди дете, ајде месец дана највише, и га крстиду, сад пођу у школу, па иду да и крстиду. Правиш повојницу ако имаш могућности, частиш кума.

Како изгледа та повојница? (А. Л.)

Ту се спреми јело, спреми се све, куји су родови, куј оће да дођу, фамилија, рођени, дођу, донесу повојницу, матери нешто, аљину, детету дрејице се купи. Ја сам и сад носила, млада из Дивича, купим дрејице, купим флашу сока, две кришке сира и једну чоколаду и сам однела повојницу и даш, и на чело детету две стотине. Свуд сам носила повојницу, макар што нисам имала децу. Сам ишла, јопет сам носила. И сам ишла.

Да ли се предсказивала судбина детету? (А. Л.)

Дете кад се роди се мете брашно, и соли, и вино, и ако се нешто дира се види 
на то, знаће да су биле милостивне; кад нема ништа, нису биле.

Да ли се стављало нешто детету против урока? (И. Ц.)

Се веже црвен конац на десну руку да нема да га неки урекне, да нема уроци.

А шта ако га урекне? (А. Л.)

Ако га урекне, треба да се баје.

А како се то ради? (А. Л.)

То се баје од урока. Бајала сам ја.

Урок седи на прагу,

Урочица под праг.

Урок уриче,

Урочица одриче.

Мушко га урекло, пукло му мудо,

Ако је женска, прсла ју сиса.

А са угљем? (И. Ц.)

Да и то. То се завати воде неначете...

Шта доноси кум детету за крштење? (И. Ц.)

Се донесе крзница, платно и се купи свећа, и на свећу машне, сад нису машне, сад се купи превез, цвеће. Сад купи кум и дрејице и све. Да га обучу у то у шта се крсти. А пре није било тако. Била више сиротиња.

Да ли се чува коса коју поп одсече детету? (И. Ц.)

Господин он то одсече и мете у воду сигурно.

\section{М. А., 1927.}

Да ли сећате када сте крстили своју децу, унуке, како је то било? (И. Ц.)

Лепо је пре било.

Ко даје име детету? (И. Ц.)

Кум му даје име. Шта кум каже, то остане... Ја знам кад сам се ја родила. Моје у кућу биле три бабе па све три Милке, а моја мајка имала кума, мало је био трговац, мислила сад куј зна које име ће да ми да, а оно све исто Милка. Пре баба ме носила у цркву. Не ко саде. Тако је ондак било кад сам се ја родила.

Да ли сте ишли код Господина за име? (И. Ц.)

Како да не. Прво на зламен добијеш име.

Како се иде за зламен? (И. Ц.)

Моја свекрва ишла за моју децу, једну флашу воде понесе...

Ког дана је крштење? (И. Ц.)

У недељу ујутру, то је било крштење. Живка, моја комшика, она млого зна. И у манастир била, и радила, Адилова мати. Њу, само њу питајте.

Да ли кум облачи дете за крштење? (И. Ц.)

Сад је мода кум обуче дете на крштење. Сад се мало роду. Сад нема ни стари ни деца.

Ко иде на крштење? (И. Ц.)

Иде једна која је баба, која носи дете, то не мајка, на прилику имаш сестру, јели зава, ти узмеш за бабу да носи дете у цркву. Било лепо, није било лоше.

Шта ради мајка док јој се дете крсти у цркви? (И. Ц.)

Тако је говор и прича да мајка треба све да мете, да пева, и да пише.

Да ли излази дете из куће пре крштења? (И. Ц.) 
И то чували. Дете док се не крсти да не иде и то.

Да ли се дете купа у цркви? (И. Ц.)

Код нас се не купа. Ја нисам ишла сас децама ја у цркву, пре моја свекрва носила.

Да ли се чува коса? (И. Ц.)

Чува се коса та.

Да ли се против урока нешто стављало? (И. Ц.)

Се мете црвен конац на руку да га не урекну. Ни ми се десило ништа, фала Богу. Деца ми била здрава, нисам ишла по лекарима, нисам нигде.

А кад се урекне? (И. Ц.)

Ја то ништа нисам радила...

Да ли се даровао кум? (И. Ц.)

Увек се даровало. Кум дарује за дете, платно једно - ћенар (ткан), у редове, па танко лепо. То је крзница, то се носи у цркву...

Сад паре носиш на повојницу.

Да ли се чека шта ће да се каже детету трећег дана, каква ће му бити судбина? (И. Ц.)

Трећи дан му суду судије.

Да ли су то милостиве? (И. Ц.)

Мој покојни отац видо милостивне. Више њи људи су седели на клупу, ноћу. Не знам у колико сати. Одједнапут су прошле неке шуштеле у бело обучене. А био бунар ту. Ни се дирали за њи. Да се дирали, би пострадали. То не смеш да дираш, каже, те милостивне, они нису дирали, само гледали кад то прошло, и право отишло у тај бунар. То толико видо. То причао мој отац покојни. Он више тако ишао тако ноћу, да чува виноград, пре било виногради, било свашта. Не знам друго да ви кажем ништа.

\section{Литература}

Аксић, 2018: Н. Аксић, Крсна слава као живи елемент традицијске културе Срба у Дунавској клисури (Румунија). Темишвар/Ниш: Исходишта, 4, 9-28.

Драгин, 2018: Г. Драгин, Из акценатске проблематике српских клисурских говора у Румунији. Темишвар/Ниш: Исходишта, 4, 61-74.

Ђорђевић Белић, 2018: С. Ђорђевић Белић, Тодоровци/тодоронциитудоронщии: прилог проучавању демонологије Срба у Дунавској клисури. Темишвар/ Ниш: Исходишта, 4, 75-88.

Жикић, 2002: Б. Жикић, Крштење одраслих и деце у Србији у последњој деценији двадесетог века, у: Обичаји животног ияиклуса у градској средини. Београд: Етнографски институт САНУ, 115-128.

Ивановић Баришић, 2018: М. Ивановић Баришић, Божић код Срба у Дунавској клисури. Темишвар/Ниш: Исходишта, 4, 89-98.

Крстић, 2015: Б. Крстић, Народни живот и обичаји Клисураца и Пољадијаца. Друго допуњено издање. Темишвар: Савез Срба у Румунији. 
Лончар Раичевић-Цветковић Теофиловић, 2018: А. Лончар Раичевић, И. Цветковић Теофиловић, О акценатским карактеристикама српских говора у Банатској клисури (Белобрешка). Темишвар/Ниш: Исходишта, 4, 159-169.

Милорадовић, 2007: С. Милорадовић, И ракйју пйјем сас мёдом. Дијалекатска скица Белобрешке (Румунија), у: Probleme de filologie slavă, XV. Timişoara: Universitatea de Vest din Timişoara, 573-580.

Милорадовић, 2013: С. Милорадовић, Прилог терминологији обичајног живота у Банатској Клисури, у: Српско језичко наслеђе на мултикултурном простору Баната. Темишвар: Савез Срба у Румунији, 127-138.

Недељков, 2013: Љ. Недељков, Културолошко истраживање лексике Срба у Румунији, у: Српско језичко наслеђе на мултикултурном простору Баната. Темишвар: Савез Срба у Румунији, 159-174.

Петровић, 2002: С. Петровић, Прежици матријархатског културног модела у ритуалима прелаза, посебно приликом рођења и свадбе, у: Обичаји животног циикулса у градској средини. Београд: Етнографски институт САНУ, 25-38.

Радуловић, 2002: Л. Радуловић, Црквени ритуали животног циклуса: крштење и венчање, у: Обичаји животног цииклуса у градској средини. Београд: Етнографски институт САНУ, 77-93.

PCAНУ, 1971: Речник српскохрватског књижевног и народног језика. Књига VII. Београд: Институт за српскохрватски језик САНУ.

РСАНУ, 1978: Речник српскохрватског књижевног и народног језика. Књига Х. Београд: Институт за српскохрватски језик САНУ.

РСГВ, 2000: Речник српских говора Војводине. Св. 1, А-Б. Нови Сад: Матица српска.

РСГВ, 2004: Речник српских говора Војводине. Св. 4, К-љ. Нови Сад: Матица српска.

Сикимић, 2018: Б. Сикимић, Теренска истраживања Срба у Клисури 2017: обичај кумачења. Темишвар/Ниш: Исходишта, 4, 309-322.

СМ, 2001: Словенска митологија. Енциколопедијски речник (Редактори: Светлана Толстој, Љубинко Раденковић). Београд: Zepter Book World.

Толстој, 1995: Н. И. Толстој. Језик словенске културе. Ниш: Просвета.

Томић, 1987: М. Томић, Говор Радимаца, у: Српски дијалектолошки зборник, XXXIII. Београд: Српска академија наука и уметности, Институт за српскохрватски језик, 311-474.

Томић 1989: М. Томић, Речник радимског говора, у: Српски дијалектолошки зборник, XXXV. Београд: Српска академија наука и уметности, Институт за српскохрватски језик, 1-173.

Трубарац Матић, 2018: Ђ. Трубарац Матић, Елементи култа предака у славским обичајима Срба из клисурских села румунског Баната (Белобрешка, Дивич, Стара Молдава). Темишвар/Ниш: Исходишта, 4, 373-383. 
Ирена Р. Цветкович Теофилович

\section{МАТЕРИАЛЫ ДЛЯ УГЛУБЛЕНИЯ ЗНАНИЯ ЛЕКСИКИ, СВЯЗАННОЙ С ОБЫЧАЕМ КРЕЩЕНИЯ У СЕРБОВ, ЖИВУЩИХ В ДУНАЙСКОМ УЩЕЛЬЕ}

\section{Резюме}

В настоящей работе обращается внимание на значение изучения лексики в отношении обычаев, связанных с рождением и крещением ребенка у сербов в деревнях Белобрешка, Дивич и Старая Молдава в Дунайском ущелье в Румынии. Наряду с хронологическим принципом описания упомянутых обычаев, в статье составлен и небольшой словарь культурологической лексики. Так как в исследованных обычаях женщине отводится значимое место, отдельное внимание уделяется лексеме бабица («повитуха»). Составление словаря культурных терминов в связи с обычаями рождения и крещения на территории сербских деревень в Дунайском ущелье в Румынии должно послужить поощрением для дальнейших исследований сербской лексики обычаев в этой области с целью получения более цельных и широких этнолингвистических представлений.

Ключевые слова: Дунайское ущелье, обычаи, рождение, крещение, этнолингвистика, культуремы. 